Л.С. Болгова, Т.Н. Туганова, Е.А. Логинова, О.И. Алексеенко, С.В. Мариненко, М.Г. Махортова, Т.М. Ярощук, Н.В. Богонис

\title{
Вклад цитопатологов в развитие морфологической диагностики онкологических заболеваний в Украине (к 100-летию Национального института рака)
}

Национальный институт рака, Киев

Получено: 5.11 .2020

Принято в печать: 4.12.2020

DOI: $10.32471 /$ clinicaloncology.2663-466X.39-3.27529

Со дня начала работы Национального института рака (НИР) Мз Украины (ранее - Киевский рентгено-радиологический и онкологический институт) научные сотрудники внесли весомый вклад в развитие цитологического метода диагностики. На основании проведенных ими цитологических исследований противораковый комитет МЗ Украины в 1948 г. признал метод цитологической диагностики обоснованным, перспективным и рекомендовал его для использования в научных разработках и в онкологической практике. Научные сотрудники патологоанатомического отделения А.В. Руденко и Л.К. Куница отдельно модифицировали метод окраски Папаниколау для более точной цитологической диагностики. А.В. Руденко по гистологическим серийным срезам удаленной опухоли установила мультифокальный тип роста рака шейки матки. Л.К. Куница впервые в мировой практике выявила и описала характерные цитоморфологические и структурные признаки мелкоклеточного (недифференцированного) рака легкого. А.Н. Мельник внедрил метод цитологического скрининга рака шейки матки, что способствовало эффективному выявлению предрака и онкопатологии шейки матки и позволило вылечить женщин с предопухолевыми состояниями. А.Н. Мельник инициировал и способствовал открытию при поддержке директора института профессора А.И. Позмогова единственной в Украине научно-исследовательской лаборатории цитологической диагностики. А.Н. Мельник опубликовал 2 книги по цитологической диагностике опухолей и 5 методических рекомендаций. Он подготовил 3 кандидатов медицинских наук, занимался подготовкой врачей-цитопатологов. Кандидат медицинских наук, заведующая научно-исследовательской лабораторией В.И. Лобода и профессор К.А. Галахин подготовили кандидата биологических наук Е.А. Логинову. В.И Лобода является соавтором 2 книг и 2 методических рекомендаций. Л.С. Болгова впервые выявила и описала цитоморфологические признаки злокачественной эпителиальной и веретеноклеточной тимом, подготовила 4 кандидатов медицинских наук, организовала и провела при активном участии сотрудников 9 научно-практических конференций и семинаров, написала и издала с участием Т.Н. Тугановой и сотрудников 3 монографии, 6 учебных пособий для цитопатологов и 8 методических рекомендаций. Профессор Л.С. Болгова подготовила к печати книгу «Цитологическая диагностика опухолей человека", при поддержке администрации лаборатории «CSD" создала ОО «Украинская ассоциация цитопатологов", организовала и провела с участием сотрудников ее первый съезд (2017). л. Болгова подготовила врачей-цитопатологов, которые в настоящее время работают в лаборатории цитологической диагностики в НИР. Научные сотрудники проводят обучение цитопатологов Украины на курсах стажировки и информации в НИР. С 2019 г. на кафедре патологической и топографической анатомии в Национальной медицинской академии последипломного образования имени. П.Л. Шупика тематические усовершенствования по цитологической диагностике опухолей проводят профессор Л.С. Болгова и кандидаты медицинских наук Т.Н. Туганова и О.И. Алексеенко. Занятия проводятся по договору между двумя учреждениями на базе лаборатории цитологической диагностики НИР.

Ключевые слова: цитопатологи; развитие; морфологическая диагностика опухолей; 100 лет Национальному институту рака.

В мировом медицинском сообществе метод цитологической диагностики широко применяется для верификации онкологических процессов. Он является незаменимым и эффективным в профилактическом направлении здравоохранения. С помощью цитологического метода решаются многие диагностические задачи при злокачественных опухолях на любом этапе их развития, включая начальный. Признанный в Европе и в мире морфолог L. Cardoso подчеркивает, что одной из задач цитологического метода является контроль гистологической диагностики [26].

В отделениях морфологии онкологических клиник США работают специалисты, которые владеют двумя морфологическими методами - цитологическим и гистологическим. Это позволяет в процессе морфологической верификации диагноза учитывать максимальное количество цитологических и гистологических признаков, то есть на клеточном и тканевом уровнях получать оптимальную информацию о патологическом процессе и, таким образом, формулировать наиболее объективное заключение.

В настоящее время существует большое количество руководств, атласов, пособий отечественных и зарубежных авторов, в которых описаны и продемонстрированы на ми- крофотографиях необходимые в ежедневной диагностической работе цитопатолога морфологические признаки злокачественных и доброкачественных новообразований всех органов и систем человека, [10, 12, 16-19, 22-25].

В Украине к развитию и становлению метода цитологической диагностики непосредственно причастны сотрудники Национального института рака (НИР).

В Киевском рентгено-радиологическом и онкологическом институте (КРРОИ) (в настоящее время - НИР) метод цитологической диагностики получил развитие с 1946 г., после изучения научными сотрудниками патологоанатомического отдела А.В. Руденко и Л.К. Куницей атласа G. Papanicolaou и H. Traut «Diagnosis of uterine cancer by the vagina smears» [28], в котором была описана полихромная окраска цитологических препаратов. Состав красителей авторы атласа не представили, и поэтому научные сотрудники приложили максимум усилий при творческом поиске в процессе подборе химических реактивов, подобных по качеству тем, которые применяли при окраске по методике G. Papanicolaou. C помощью подобранных красителей можно было определять состояние клеток в зависимости от степени дифференцировки, что имеет 
существенное значение в цитологической диагностике предраковых поражений и рака.

После успешного завершения работы по поиску и подбору реактивов были созданы две авторские модификации методики G. Papanicolaou: «Методика окраски по G. Papanicolaou в модификации А.В. Руденко» (окраска лихтгрюн-оранжем) и «Методика окраски по G. Papanicolaou в модификации Л.К. Куницы». Методики опубликованы в тематическом журнале и в виде методических рекомендаций (МР). В современных пособиях для врачей «Цитологический скрининг рака шейки матки» $[2,4,8]$ приводятся модифицированные методики окраски упомянутых авторов нашего института.

Апробация разработанных модификаций позволила внедрить их в научные исследования и практическое здравоохранение. До настоящего времени они широко используются в цитологических лабораториях Украины и других стран СНГ.

Для обоснования возможности цитологической диагностики рака шейки матки (РШМ) А.В. Руденко провела исследования материала 1024 больных. Изучено более 3 тыс. цитологических препаратов. В процессе исследований она подробно описала цитологические особенности элементов плоскоклеточного РШМ.

Проведенные на большом клиническом материале цитологические исследования в сопоставлении с гистологическими результатами позволили А.В. Руденко получить достоверное гистологическое обоснование возможности цитологической диагностики РШМ, в том числе ранних его стадий. Результаты изысканий представлены в диссертационной работе «Цитологическая диагностика рака шейки матки», которую она успешно защитила в Научноисследовательском институте онкологии им. Н.Н. Петрова в Ленинграде в 1954 г. На основании выполненных исследований А.В. Руденко также делает вывод о возможности использования цитологического метода при массовых профилактических гинекологических осмотрах женщин [20].

Исследования, проведенные А.В. Руденко на сотнях серийных гистологических срезов удаленных опухолей шейки матки, позволили доказать, что РШМ развивается мультицентрично. При этом на одном участке видны предраковые изменения, на другом - рак на месте (cancer in situ), на третьем - инфильтративный рост. Результаты исследований позволили А.В. Руденко прийти к концептуальному заключению о мультифокальном развитии РШМ и представить материалы в виде монографии «Морфогенез плоскоклеточного рака шейки матки» [20]. До настоящего времени издание не потеряло своего фундаментального значения в гистологической и цитологической диагностике и является образцом морфологического исследования в патологической анатомии.

А.В. Руденко впервые описала закономерности морфогенеза РШМ и получила принципиально новые гистологические данные, которые внесли достойный научный вклад в развитие онкоморфологии и онкологии в целом.

В то же время научный сотрудник Л.К. Куница исследовала эксфолиативный легочный материал с целью цитологической верификации заболеваний легкого. Ей удалось по материалу мокроты диагностировать рак легкого у $85 \%$ обследованных больных, направленных в институт для уточнения диагноза и возможного лечения.

Исследования объемного диагностического материала, верифицированного гистологическим методом, позволили Л.К. Кунице в 1958 г. защитить кандидатскую диссертацию «Диагностика рака легкого методом цитологического исследования мокроты». В процессе научного поиска Л.К. Куница впервые в мировой практике выявила и описала характерные цитоморфологические и структурные признаки мелкоклеточного (недифференцированного) рака легкого. Научная статья на эту тему была признана лучшей тематической работой года и рекомендована для публикации в ежегоднике по раку в штате Техас, США [27].

Проведенная тщательная работа по эксфолиативной цитологической диагностике рака легкого, а также поиск и изучение мировой литературы по истории развития цитологического метода позволили Л.К. Кунице подготовить и опубликовать весьма значимую для цитопатологов Украины и других стран монографию - «Цитоморфологическая диагностика рака легкого» [15].

Выполненные доказательные морфологические исследования на материале опухолей двух локализаций шейки матки и легкого позволили подготовить объемный верифицированный материал, который стал основанием для постановки вопроса перед Министерством здравоохранения Украины о рассмотрении возможности применения цитологического метода для верификации раковых новообразований в стране.

Полученные убедительные и наглядные результаты исследований киевских ученых под руководством кандидата медицинских наук Т.С. Шведковой-Роше были представлены в 1948 г. на заседании Противоракового комитета Министерства здравоохранения Украины.

Эффективность, достоверность и относительная простота выполнения диагностической процедуры методом цитологического исследования были настолько убедительными, что метод признан обоснованным и перспективным. Принято решение рекомендовать его для научной разработки и практического применения в онкологической практике Украины.

Заключение Противоракового комитета Украины стало тем решающим шагом, который обеспечил последующее успешное развитие метода цитологической диагностики коллективом сотрудников КРРОИ под руководством Т.С. Шведковой-Роше при поддержке директора института профессора И.Т. Шевченко.

В 1950 г. в Киеве состоялась 1-я Республиканская проблемная научная конференция, посвященная цитологической диагностике рака. В конференции приняли участие ученые и специалисты в области онкологии из разных городов Украины и России. Это событие ознаменовало новую эру в отечественной морфологической диагностике, эру с применением цитологического метода. В решении конференции было подчеркнуто, что метод имеет огромное значение в диагностике предраковых состояний и рака на любой, в том числе, начальной стадии его развития.

Таким образом был дан старт проведению скрининга РШМ.

В дальнейшем метод цитологической диагностики вошел в клиническую онкологию как неотъемлемый, важный способ морфологической диагностики опухолей различных локализаций. Его последовательному развитию и внедрению в онкологическую практику Украины способствовали известные научные сотрудники КРРОИ - А.В. Руденко, Л.К. Куница и А.Н. Мельник. Именно они обосновали достоверность, эффективность метода цитологической диагностики и проводили научную разработку признаков онкологических процессов различных органов.

Накопленный опыт по цитологической диагностике наиболее часто выявляемых онкологических заболеваний, таких как РШМ и рак легкого, позволил сотрудникам института проводить подготовку специалистов по клинической цитологии районных, областных и городских онкологических диспансеров всей страны.

Достойный вклад в развитие и внедрение метода цитологической диагностики внес профессор А.Н. Мельник [11, $16,17]$, который способствовал популяризации, развитию и организации цитологического скрининга в Украине. Работая патологоанатомом, он заинтересовался методом 
цитологической диагностики и стал проводить соответствующие научные исследования под руководством профессора М.К. Даля, который возглавлял кафедру патологической анатомии Киевского института усовершенствования врачей (ныне - Национальная медицинская академия последипломного образования имени П.Л. Шупика - НМАПО им. П.Л. Шупика). А.Н. Мельнику удалось выявить и описать цитологические признаки, характерные для ряда онкологических процессов. Результаты исследований молодой ученый оформил и представил в виде кандидатской диссертации на тему «Материалы к вопросу о срочной клинико-микроскопической диагностике рака матки и молочной железы» (1958).

С 1960 г. А.Н. Мельник возглавил патологоанатомическое отделение КРРОИ, где он смог продолжить научные поиски. Проведенные им многочисленные цитоморфологические и цитохимические исследования с применением комплекса современных методик позволили ученому выявить новые данные и опубликовать наблюдения в специализированных журналах, а также подготовить и защитить в 1970 г. докторскую диссертацию на тему «Комплексная макроскопическая и цитологическая диагностика опухолей молочной железы».

После того, как был принят известный приказ от 30.12.1976 г. № 1253 МЗ СССР «О мерах по улучшению цитологической диагностики злокачественных новообразований» в Украине при активном участии А.Н. Мельника были организованы и функционируют по настоящее время централизованные цитологические лаборатории (ЦЦЛ) в городских и областных клинических онкологических диспансерах. Врачи ЦЦЛ проводят большую работу по диагностике опухолей различных локализаций и по цитологическому скринингу рака шейки матки. Ежегодно они присылают отчеты о проведенной работе в НИР профессор Л.С. Болговой, которая анализирует их и докладывает на научно-практических конференциях и семинарах.

В 70-х годах ХХ ст. в Украине А.Н. Мельником организован цитологический скрининг РШМ. Его постоянная подвижническая деятельность и обучение учащихся на курсах стажировки и информации института позволили повысить уровень знаний специалистов по диагностике предраковых изменений и РШМ. Повышение квалификации врачей-цитопатологов способствовало повышению эффективности цитологической диагностики заболеваний шейки матки. При этом гинекологи смогли более обоснованно проводить адекватное лечение пациенток при предраковых состояниях и тем самым предупредить развитие инфильтративных форм рака, что имеет важное медицинское, социальное, общегосударственное значение и направлено на сохранение генофонда Украины.

Результаты работы были представлены на итоговых годовых областных совещаниях и семинарах. Это позволило повысить ответственность гинекологов и цитопатологов за проведение скрининга, что в результате способствовало повышению уровня выявления ранних форм РШМ в 3-4, а предраковых состояний - в 15-20 раз. Об этом свидетельствуют сравнительные данные ежегодно издаваемого Бюллетеня канцер-регистра Украины в разные годы [21].

Доктор медицинских наук, професор А.Н. Мельник внес значимый вклад в развитие и внедрение цитологического метода в онкологическую практику в Украине. Так, одним из знаменательных событий для развития цитологической диагностики в Украине стало создание в 1971 г. в составе патологоанатомического отдела КРРОИ научно-исследовательской лаборатории цитологической диагностики. Его инициатором был профессор А.Н. Мельник при активной поддержке директора института, профессора А.И. Позмогова.
Открытие научно-исследовательской лаборатории стало важной вехой в развитии метода цитологической диагностики в Украине. Появилась возможность проводить исследования по выявлению неизвестных цитологических признаков опухолей различного происхождения, что способствовало качественной цитологической диагностике опухолей, предопухолевых состояний, дифференциальной диагностике опухолевых и неопухолевых процессов. Все было направлено на совершенствование цитологической диагностики онкологических заболеваний

На уровне цитологических исследований при сопоставлении с гистологическими данными выявляли признаки редко выявляемых новообразований, не представленных в доступной литературе.

В лаборатории созданы коллекции учебных музейных препаратов для подготовки врачей по цитологической диагностике опухолей различных органов. Научные сотрудники стали обучать цитопатологов по программе курсов информации и стажировки. Кроме того, появилась возможность организации и проведения научно-практических конференций и семинаров по цитологической диагностике опухолей для специалистов Украины и других стран.

При изучении цитоморфологических признаков опухолевых клеток разного генеза А.Н. Мельник внедрил комплекс методов исследований: нативной, суправитальной и люминесцентной микроскопии в сопоставлении с окрашенными цитологическими препаратами и результатами гистологических исследований.

Оригинальность научных исследований и публикаций А.Н. Мельника, его учеников и сотрудников отмечены академиком Академия медицинских наук (АМН) СССР А.И. Струковым как «значительный вклад в разработку различных вопросов современной онкоморфологии». Высоко оценивая профессиональные качества ученого и его вклад в развитие специальности, Американский комитет премиального ракового фонда (American Cancer Society Award) удостоил профессора Анатолия Никитовича Мельника права выдвигать на конкурс работы по онкологии.

Анатолий Никитович активно участвовал в общественной жизни, был членом 3 ученых советов, Всесоюзной проблемой комиссии АМН СССР «Морфология опухолей», неоднократно избирался членом правления республиканских и городских научно-практических обществ по специальностям: «Онкология», «Патологическая анатомия», «Лабораторное дело». Он принимал активное участие в организации и проведении пленумов, конференций и съездов, выступая с докладами, сообщениями и предложениями.

Большой опыт в цитологической диагностике злокачественных и доброкачественных опухолей с применением комплекса цитологических методов позволил прекрасному специалисту - патологоанатому и одновременно клиническому цитологу А.М. Мельнику издать ряд чрезвычайно важных для дальнейших научных разработок и для практики цитопатологов книг: «Цитоморфологическая диагностика опухолей молочной железы» [16], «Цитоморфологическая диагностика опухолей» [17]. В последней автор представил профессиональный иллюстративный материал на тканевом и клеточном уровнях исследований. На международной выставке книг медицинских издательств текущего года это издание удостоено диплома I степени.

Анатолий Никитович также является соавтором книги «Диагностика предопухолевых и опухолевых процессов шейки матки» (К.П. Ганина, Е.В. Коханевич, А.Н. Мельник) [11].

Серьезное внимание уделял А.Н. Мельник подготовке научных кадров и специалистов для практического здравоохранения. Под его непосредственным руководством защищены диссертации на соискание ученой степени 
кандидата медицинских наук на темы «Цитоморфология и цитологическая диагностика некоторых видов злокачественных опухолей мягких тканей», С.А. Сильченко (1978), «Цитологическая диагностика опухолей и кист средостения», Л.С. Болгова (1980).

Используя комплекс цитологических методов исследования, С.А. Сильченко изучила структурную организацию опухолевых клеток, которые характеризуют новообразования жировой и синовиальной тканей, что способствовало более точной идентификации их гистологического типа.

Л.С. Болговой с применением вышеупомянутого комплекса цитологических исследований изучены опухоли вилочковой железы. Впервые описаны цитоморфологические признаки злокачественной эпителиальной и веретеноклеточной тимом, которые не были представлены в известных отечественных и зарубежных руководствах и монографиях.

Научно-исследовательскую лабораторию цитологической диагностики с 1979 по 2000 гг. возглавляла кандидат медицинских наук В.И. Лобода, которая в 1966 г. под руководством профессора К.П. Ганиной защитила кандидатскую диссертацию на тему «Половой хроматин в молочных железах женщин при предопухолевых и опухолевых процессах».

В.И. Лобода является соавтором 2 монографий: «Иммунология и иммунотерапия молочной железы» [13] и «Рак щитовидной железы. Эпидемиологические, радиобиологические и иммуноэндокринологические аспекты с обоснованием иммунотерапии» [14].

В 1986 г. организована цитологическая служба в рентген-хирургическом кабинете института, в котором под руководством Л.С. Болговой и ее непосредственном участии на протяжении 10 лет Т.Н. Тугановой проводилась срочная цитологическая диагностика заболеваний легких и средостения в процессе получения материала из опухоли.

Под руководством профессора К.А. Галахина и заведующий научно-исследовательской лаборатории цитологической диагностики, кандидата медицинских наук В.И. Лободы в 1992 г. Е.А. Логинова защитила диссертацию на соискание ученой степени кандидата биологических наук на тему «Цитоморфологическая и морфофункциональная характеристика реактивних изменений бронхиального эпителия при раке легкого по материалу фибробронхоскопий», в которой отражена возможность цитологической диагностики реактивных изменений бронхиального эпителия При выполнении диссертационной работы Е.А. Логинова внедрила в лабораторию метод окраски по W.M. Howell, D.A. Black и предложила переокрашивание архивных препаратов по названной методике.

Под руководством профессора, члена-корреспондента АМН Украины В.Л. Ганула и кандидата медицинских наук Л.С. Болговой Т.Н. Туганова защитила кандидатскую диссертацию на тему «Срочная цитологическая диагностика при рентген-хирургическом исследовании новообразований легких и средостения» (1992). Автором показана возможность цитологической верификации морфологического диагноза по пункционному материалу новообразований легкого до $94,2 \%$ и средостения - до $92,1 \%$ наблюдений.

Т.Н. Туганова совместно с соискателем И.С. Танасийчук применили модифицированную окраску архивных препаратов с использованием термостатной технологии окрашивания для количественной оценки и качественной идентификации ядрышковых организаторов. Разработаны рабочие схемы оценки морфофункциональных типов ядрышковых организаторов и их переходных форм, на основании которых проводятся объективные и достоверные исследования показателей дифференциальной диагностики доброкачественных и злокачественных новообразований.
Выполнена и защищена докторская диссертация на тему «Рак легені і бронхіальний епітелій (цитоморфологічні, цитометричні, цитогенетичні та гістологічні дослідження» Л.С. Болговой (1994). При этом убедительно показано, что легкая дисплазия бронхиального эпителия наблюдается как при раке, так и при нераковых заболеваниях легкого. Умеренная и тяжелая дисплазия бронхиального эпителия характерна только для раковых поражений органа. Установлено, что при снижении степени дифференцировки наиболее часто отмечаемых плоскоклеточной и железистой форм рака легкого цитоморфологические признаки имеют морфологическое сходство.

С 2000 г. научно-исследовательскую лабораторию клинической цитологии возглавила доктор медицинских наук Л.С. Болгова. Под ее руководством защищены несколько кандидатских диссертаций, научным сотрудником О.И. Алексеенко - диссертация на тему «Цитоморфологічні, морфометричні і цитогенетичні ознаки медіастинальних дрібноклітинних пухлин» (2005). Автором разработаны дифференциально-диагностические цитологические признаки сложных для верификации мелкоклеточных опухолей средостения. И.С. Танасийчук выполнила и защитила диссертацию на тему «Цитологічні показники лімфатичних вузлів в нормі, при хронічних лімфаденітах та дрібноклітинних лімфосаркомах: квантифікаційний аналіз» (2006). Автор определила количественный состав лимфоидных элементов в лимфатических узлах человека в норме в возрастном аспекте. Разработала количественные показатели клеточного состава лимфатических узлов по пункционному материалу у пациентов с лимфаденитом и мелкоклеточными лимфомами. В 2019 г. врач лаборатории цитологической диагностики С. В. Мариненко защитила диссертацию «Диференційна цитологічна діагностика аденокарциноми, мезотеліоми та реактивного серозиту». В процессе подготовки диссертационных материалов ей удалось определить тот минимум современных методических приемов, который позволяет провести дифференциальную диагностику первичных и вторичных поражений при исследовании содержимого серозных полостей.

Под руководством профессора Л.С. Болговой ведущий научный сотрудник Т.Н. Туганова, заведующая лабораторией цитологической диагностики Е.А. Логинова, врачи О.И. Алексеенко, С.В. Мариненко, Т.М. Ярощук, М.Г. Махортова ежедневно проводят цитологическую диагностику опухолей различного генеза с определением гистологического типа и степени дифференцировки по эксфолиативным и пункционным материалам. Ежегодно в лаборатории проводится более 35 тыс. цитологических исследований материалов, которые поступают из поликлинического отделения, стационара и манипуляционных кабинетов.

В связи с тем, что в медицинских университетах не преподается цитопатология, вновь поступивших на работу в лабораторию молодых врачей профессор Л.С. Болгова обучает методу цитологической диагностики, начиная от признаков клеток каждого органа и ткани в норме до развития предраковых состояний, рака различных гистологических типов и степени дифференцировки, сарком всех видов тканей. Занятия на архивном и текущем материале проводятся в течение года. В процессе повседневной диагностики опытные специалисты консультируют в случае выявления сложных для морфологической верификации цитологических препаратов.

Профессором Л.С. Болговой и врачом С.В Мариненко ценой невероятных усилий, ввиду большой затратности и отсутствия финансирования науки, удалось внедрить методы иммуноцитохимических исследований в повседневную практику. Иммуноцитохимические исследования 
в настоящее время активно и успешно проводятся сотрудниками лаборатории С.В. Мариненко, Т.М. Ярощук, М.Г. Махортовой и биологом Н.В. Богонис, что позволяет обеспечивать высокий уровень диагностики.

Кандидатом медицинских наук, ведущим научным сотрудником Т.Н. Тугановой проведены морфометрические исследования клеток тимом, что имеет важное значение для дифференциальной диагностики с медиастинальными лимфомами у молодых пациентов. Ею выполнены уникальные исследования по изучению лечебного патоморфоза различных гистологических типов рака легкого по пункционному материалу опухоли, результаты которых представлены на европейских и международных конгрессах.

Научными сотрудниками и врачами лаборатории постоянно оказывается помощь практическому здравоохранению в виде издания пособий для врачей. Под руководством профессора Болговой при активном участии ведущего научного сотрудника, кандидата медицинских наук Т.Н. Тугановой подготовлены и опубликованы МР: по цитологической диагностике лимфопролиферативных заболеваний, опухолям грудной железы, дисплазиям плоского и цилиндрического эпителия, плоскоклеточного и железистого РШМ, опухолям яичников, печени, поджелудочной железы, дифференциальной диагностике аденокарциномы, мезотелиомы и реактивного мезотелия. В подготовке МР приняли участие: О.И. Алексеенко, М.Г. Махортова, Т.М. Ярощук и С.В. Мариненко.

Профессором Л.С. Болговой разработаны и описаны цитологические признаки переходноклеточного рака мочевого пузыря по материалам осадка мочи и изданы МР, которые востребованы во всех клинических лабораториях Украины для выявления ранних и более поздних стадий этого заболевания. В материалах МР представлены не только текстовые материалы касательно рака мочевого пузыря, но и поданы хорошего качества микрофотографии, которые позволят всем врачам клинических лабораторий диагностировать опухоли на любой стадии экзофитного роста. Данный способ выявления рака мочевого пузыря по материалам осадков мочи является скрининговым, то есть таким, который позволяет выявлять онкопатологию при бессимптомном клиническом течении.

Кандидат медицинских наук О.И. Алексеенко совместно с заведующей научно-исследовательской лаборатории экспериментальной онкологии доктором биологических наук Н.Н. Храновской участвовала в разработке методики приготовления препаратов культуры дендритных клеток, позволившей визуализировать, изучать их цитологические особенности в процессе дифференцировки и приготовления противоопухолевых вакцин (2006 г.). Кроме того, О. И. Алексеенко была молодым ученым - стипендиатом Кабинета Министров Украины (2007-2009). В настоящее время она является секретарем Совета НИР по апробации диссертаций.

Сотрудниками лаборатории опубликовано более 700 научных работ. Под руководством профессора Л.С. Болговой и активном участии ведущего научного сотрудника Т.Н. Тугановой подготовлены к публикации и изданы монографии: «Пункционная цитологическая диагностика новообразований средостения» [1], «Рак легкого: вопросы гистогенеза и цитологической діагностики» [6], «Метод цитологической диагностики в Украине (краткая история развития и становления)» [7]. Изданы также пособия для врачей: «Цитологический скрининг рака шейки матки» [2], которое оказалось настолько востребованным, что дважды возникала необходимость в его переиздании в 2011 г. [4] и в 2017 г. [8]; «Цитоморфологическая диагностика заболеваний грудной железы» [3]; «Методы получения материала для цитологической диагностики опухолей» [5], а также учебное пособие «Цитологія органів і тканин людини» [9]. Л.С. Болговой подготовлена к изданию книга «Цитологічна діагностика пухлин людини».

Совместно с сотрудниками научно-исследовательской лаборатории клинической цитологиии и лаборатории цитологической диагностики с 2001 г. организованы и проведены 9 научно-практических конференций и семинаров, на которых рассматривались актуальные диагностические вопросы для цитопатологов Украины. Была создана Украинская ассоциация цитопатологов и проведен первый съезд цитопатологов Украины (2017). Президентом Украинской ассоциации цитопатологов избрана профессор Л.С. Болгова. На съезде принята резолюция, одним из пунктов которой являлось обращение на имя ректора НМАПО им. П.Л. Шупика, академика АМН Украины Ю.В. Вороненко о необходимости создания специального учебного курса по подготовке цитопатологов в Украине.

В настоящее время на кафедре патологической и топографической анатомии НМАПО им. П.Л. Шупика проводятся учебные занятия по цитопатологии, но курсанты обучаются на базе лаборатории цитологической диагностики НИР. Занятия проводят доктор медицинских наук, профессор Л.С. Болгова, кандидат медицинских наук, старший научный сотрудник Т.Н. Туганова и кандидат медицинских наук О.И. Алексеенко.

Таким образом, ученые НИР внесли значимый вклад в развитие метода цитологической диагностики, обогатив морфологическую науку новыми данными. Гистологические исследования позволили установить, что раковые опухоли развиваются мультицентрично, начиная от предраковых изменений и заканчивая инфильтративной формой (А.В. Руденко). Были выявлены новые, ранее не описанные в мировой литературе, цитоморфологические признаки мелкоклеточного рака легкого (Л.К. Куница), злокачественной эпителиальной и веретеноклеточной тимом (Л.С. Болгова). Также ученые НИР обосновали и внедрили цитологический скрининг в Украине (А.В. Руденко, А.Н. Мельник), разработали методику с применением количественного учета РНКсодержащих структур - морфофункциональных типов ядрышек, которая позволяет проводить дифференциальную диагностику доброкачественных и злокачественных опухолей (Т.Н. Туганова). Сотрудниками лаборатории постоянно проводится цитологическая диагностика опухолей по эксфолиативным и пункционным материалам, осуществляются консультации цитологических препаратов из всех лечебных учреждений Украины.

Под руководством профессора Л.С. Болговой изданы монографии, пособия и МР по цитологической диагностике опухолей различных локализаций для цитопатологов. Создана Украинская Ассоциация цитопатологов при поддержке администрации лаборатории «CSD», проведен первый ее съезд, организовываются и проводятся ежегодные научно-практические конференции по актуальным вопросам цитологической диагностики онкологических заболеваний.

Подводя итоги к 100-летию НИР, необходимо отметить, что украинская школа цитологической службы уверенно продолжает развиваться, вносит весомый вклад в виде научных разработок, значимых публикаций для дальнейшего усовершенствования морфологического метода в Украине. Необходимо подчеркнуть что все цитологические исследования направлены на разработку скрининговых тестов и повышение качества диагностики опухолей для улучшения эффективности лечения больных.

\section{СПИСОК ИСПОЛЬЗОВАННОЙ ЛИТЕРАТУРЫ}

1. Болгова, Л. С., Туганова, Т.Н., Галахин, К. А., Ганул, А. В., Бабий, Я. С., Родзаевский, С. А., \& Клапчук, А. Г. (2004). Пункционная цитологическая диагностика новообразований средостения. Киев, 128.

2. Болгова, Л. С., Туганова, Т. Н., Воробьева, Л. И., Жилка, Н. Я., \& Махортова, М. Г. (2007). Цитологический скрининг рака шейки матки (пособие для врачей). Киев: СПД Коляда О.П. 
3. Болгова, Л. С., Туганова, Т. Н., \& Смоланка, И. И. (2010). Цитоморфологи ческая диагностика заболеваний грудной железы (учебное пособие для врачей) Киев: Издательство «Интерсервис».

4. Болгова, Л. С., Туганова, Т. Н., Цип, Н. П., Жилка, Н. Я., \& Махортова, М. Г. (2011). Цитологический скрининг рака шейки матки (учебное пособие для врачей) (2-е изд.). Киев: СПд Коляда О.П.

5. Болгова, Л. С., Туганова, Т. Н., Родзаевский, С. А., Процык, В. С., Воробьева, Л. И., \& Попсуй, В.В. (2011). Методы получения материала для цитологической диагностики опухолей (пособие для врачей). Киев: Издательство КИМ.

6. Болгова, Л. С., \& Туганова, Т. Н. (2013). Рак легкого: вопросы гистогенеза ицитологической диагностики. Киев: КИМ.

7. Болгова, Л. С., Туганова, Т. Н., \& Оношко, М. М. (2015). Метод цитологической диагностики в Украине (краткая история развития и становления). Киев: КИМ

8. Болгова, Л. С., Туганова, Т. Н., Цип, Н. П., Жилка, Н. Я., \& Махортова, М. Г. (2017). Цитологический скрининг рака шейки матки (учебное пособие для врачей) (3-е ид.). Киев: Профессионал Инвест.

9. Болгова, Л. С. (Ред.) (2018). Цитологія органів і тканин людини. Київ: Книга-плюс.

10. Волченко, Н. Н., \& Борисова, О. В. (2018). Диагностика злокачественных опухолей по серозным экссудатам. Цитологический атлас. Москва: ГЭОТАРМедиа.

11. Ганина, К. П., Коханевич, Е. В., \& Мельник, А. Н. (1984). Диагностика предопухолевых и опухолевых процессов шейки матки. Киев: Наукова думка.

12. Глузман, Д. Ф., Скляренко, Л. М., \& Нагорная, В. А. (2011). Диагностическая онкогематология. Киев: ДИА

13. Гриневич, Ю. А., Каменец, Л. Я., Былинский, Б. Т., \& Лобода, В. И. (1990) Иммунология и иммунотерапия молочной железы. Киев: Здоров'я.

14. Гриневич, Ю. А., Чумак, А. А. (Ред.) (2011). Рак щитовидной железы. Эпидемиологические, радиобиологические и иммуноэндокринологические аспекты с обоснованием иммунотерапии. Киев: Здоров'я.

15. Куница, Л. К. (1985). Цитоморфологическая диагностика рака легкого. Киев: Наукова думка.

16. Мельник, А. Н. (1975). Цитоморфологическая диагностика опухолей молочной железы. Киев: Здоров'я.

17. Мельник, А. Н. (1983). Цитоморфологическая диагностика опухолей (2-е изд.). Киев: Здоров'я.

18. Новик, В. И. (2017). Атлас цитоморфологической диагностики новообразований кожи. Москва: Книга по требованию.

19. Петрова, А. С., \& Птохов, М. П. (1976). Руководство по цитологической диагностике опухолей человека. Москва: Медицина.

20. Руденко, А. В. (1972). Морфогенез плоскоклеточного рака шейки матки. Киев: Здоров'я.

21. Федоренко, З. П., Гулак, Л. О., Михайлович, Ю. Й., Горох, Є. Л., Рижов, А. Ю., Сумкіна, О. В., \& Куценко, Л. Б. (2020). Рак в Україні, 2018-2019. Захворюваність, смертність, показники діяльності онкологічної служби / гол. ред. О.О. Колеснік. Бюлетень Національного канцер-реєстру України, 21, 145.

22. Шабалова, И. П., \& Касоян, К. Т. (2016). Цитология жидкостная и тради ционная при заболеваниях шейки матки. Цитологический атлас. Москва: Триада. 23. Шапиро, Н. А., Батороев, Ю. К., \& Дворниченко, В.В. (2012). Цитологическая диагностика заболеваний печени, желчного пузыря и поджелудочной железы. Цветной атлас. Москва-Иркутск.

24. Шапиро, Н. А., Батороев, Ю. К., Дворниченко, В. В., \& Бакланова, О. В. (2014). Цитологическая диагностика заболеваний органов мочевой системы: Цветной атлас. Москва-Иркутск.

25. Шапиро, Н. А., \& Батороев, Ю. К. (2015). Цитологическая диагностика заболеваний кожи: Цветной атлас. Москва: РепроцентрМ.

26. Cardozo, P. L. (1976). Atlas of clinical cytology. Netherlands: Med. Klin. Leiden Univ.

27. Kunitsa, L. K. (1959). Some new data concerning of the morphology of lung cancer cells found in sputum. Houston: Univ. Texas.

28. Papanicolaou, G. N., \& Traut, H. F. (1943). Diagnosis of uterine cancer by the vaginal smears. New York: Commonwealth Fund.

Внесок цитопатологів у розвиток морфологічної діагностики онкологічних захворювань в Україні (до 100-річчя Національного інституту раку)

Л.С. Болгова, Т.М. Туганова, С.О. Логінова, О.І.Алексєєнко,

С.В. Мариненко, Т.М. Ярошук, М.Г. Махортова, Н.В. Богоніс

Національний інститут раку, Київ

3 дня початку роботи Національного інституту раку (НIP) МОЗ України (раніше - Київський рентгено-радіологічний та онкологічний інститут) наукові співробітники робили вагомий внесок у розвиток цитологічного методу діагностики. На підставі проведених ними цитологічних досліджень Протираковий комітет МОЗ України в 1948 р. визнав метод цитологічної діагностики обгрунтованим, перспективним і рекомендував його для використання в наукових розробках і в онкологічній практиці. Науков співробітники патологоанатомічного відділення Г.В. Руденко і Л.К. Куниця окремо модифікували метод забарвлення Папаніколау для більш точної цитологічної діагностики. Г.В. Руденко за гістологічними серійними зрізами видаленої пухлини встановила мультифокальний тип росту раку шийки матки. Л.К. Куниця вперше в світовій практиці виявила і описала характерні цитоморфологічні і структурні ознаки дрібноклітинного (недиференційованого) раку легені. А.М. Мельник впровадив метод цитологічного скринінгу раку шийки матки, що сприяло ефективному виявленню передраку і онкопатології шийки матки і дозволило вилікувати жінок з передпухлинними станами. А.М. Мельник ініціював і сприяв відкриттю за підтримки директора інституту професора А.І. Позмогова єдиної в Україні науково-дослідної лабораторії цитологічної діагностики. А.М. Мельник опублікував 2 книги з цитологічної діагностики пухлин і 5 методичних рекомендацій. Він підготував 3 кандидатів медичних наук, займався підготовкою лікарів-цитопатологів. Кандидат медичних наук, завідувач науково-дослідної лабораторії В.І. Лобода і професор К.А. Галахін підготували кандидата біологічних наук Е.А. Логінову. В.І. Лобода є співавтором 2 книг і 2 методичних рекомендацій. Л.С. Болгова вперше виявила і описала цитоморфологічні ознаки злоякісної епітеліальної і веретеноклітинної тімом, підготувала 4 кандидатів медичних наук, організувала й провела за активної участі співробітників 9 науково-практичних конференцій і семінарів, написала і видала за участю Т.М. Туганової і співробітників 3 монографії, 6 навчальних посібників для цитопатологів i 8 методичних рекомендацій. Професор Л.С. Болгова підготувала до друку книгу «Цитологічна діагностика пухлин людини», за підтримки адміністрації лабораторії «CSD» створила ГО «Українська асоціація цитопатологів», організувала і провела за участю співробітників її перший з'їзд (2017). Л.С. Болгова підготувала лікарів-цитопатологів, які на даний час працюють в лабораторії цитологічної діагностики в НІР. Наукові співробітники проводять навчання цитопатологів України на курсах стажування та інформації в НIP. 32019 р. на кафедрі патологічної та топографічної анатомії в Національній медичній академії післядипломної освіти ім. П.Л. Шупика тематичні удосконалення з цитологічної діагностики пухлин проводять професор Л.С. Болгова і кандидати медичних наук Т.М. Туганова і О.І. Алексеєнко. Заняття проводяться за договором між двома установами на базі лабораторії цитологічної діагностики НІР.

Ключові слова: цитопатологи; розвиток; морфологічна діагностика пухлин; 100 років Національному інституту раку.

The contribution of cytopathologists to the development of morphological diagnostics of oncological diseases in Ukraine (to the 100th anniversary of the National Cancer Institute)"

L.S. Bolgova, T.N. Tuganova, E.A. Loginova, O.I. Alekseenko, S.V. Marinenko, T.M. Yarochuk, M.G. Makhortova, N.V. Bogonis

National Cancer Institute, Kyiv

From the day of existence and the beginning of the research work of the National Cancer Institute of Ukraine (former KRROI), the researchers have made a significant contribution to the development of the cytological diagnostic method. On the basis of their cytological studies, the Anticancer Committee of the Ministry of Health of Ukraine in 1948 recognized the method of cytological diagnostics as reasonable, promising and recommended it for use in scientific research and in oncological practice. Researchers of the pathological department A. Rudenko and L. Kunitsa independently of each other modified the Papanicolau staining method for more accurate cytological diagnosis. A. Rudenko on the histological serial sections of the removed tumor established the multifocal type of growth of cervical cancer. L. Kunitsa was the first in world practice to discover and describe the characteristic cytomorphological and structural signs of small cell (undifferentiated) lung cancer. A. Melnik introduced a method of cytological screening for cervical cancer, which contributed to the efficiency of detecting precancerous and cervical cancer and made it possible to cure women with precancerous conditions. A. Melnik initiated and facilitated the opening, with the support of the director of the institute, professor A. Pozmogov, the only one research laboratory of cytological diagnostics in Ukraine. A. Melnik prepared and published 2 books 
of cytological diagnosis of tumors and 5 methodical recommendations. He trained 3 candidates of medical sciences. He was teach of cytopathologists. Candidate of medical sciences, the head of research laboratory V. Loboda and professor K. Galakhin was trained by the candidate of biological sciences E. Loginova. V. Loboda is a co-author of 2 books and 2 methodical recommendations. L. Bolgova was the first to discover and describe the cytomorphological signs of malignant epithelial and spindle cell thymoma. She trained 4 candidate of medical sciences, organized and conducted 9 scientific and practical conferences and seminars with the active participation of employees. Wrote and published with the participation T. Tuganova and colleagues 3 monographs, 6 textbooks for cytopathologists and 8 methodical recommendations. Professor L. Bolgova prepared for publication the book «Cytological diagnosis of tumors of human». She created the public association «Ukrainian Association of Cytopathologists» with the support of the administration of the "CSD» laboratory, organized and held its first congress with the participation of employees (2017). L. Bolgova trained doctors-cytopathologists who are currently working in the laboratory of cytological diagnostics in the National Cancer Institute. She conducts train cytopathologists of Ukraine at probation and information courses with the participation of researchers. Since 2019, at the Department of Pathological and Topographic Anatomy at the National medical academy of postgraduate education name P. Shupik, L. Bolgova and candidate of medical sciences T. Tuganova and $\mathrm{O}$. Alekseenko are teach on the thematic improvements of cytological diagnosis of tumors. Classes are held under an agreement between two institutions at the Laboratory of cytological diagnostics of the National Cancer Institute of Ukraine.

Key words: cytopathologists; development; morphological diagnosis of tumors; 100 years of the National Cancer Institute.

Адрес:
Болгова Лидия Севастьяновна
03022, Киев, ул. Ломоносова, 33/43
Национальный институт рака
Tел.: (044) 257-51-59
$\begin{aligned} & \text { E-mail: Bolgova2006@ukr.net } \\ & \text { 33/43 Lomonosov Str., Kyiv 03022 } \\ & \text { Correspondence: } \\ & \text { National Cancer Institute } \\ & \text { Tel.: (044) 257-51-59 } \\ & \text { E-mail: Bolgova2006@ukr.net }\end{aligned}$

